\title{
Al-Mizan
}

ISSN 1907-0985 E ISSN 2442-8256

Volume 12 Nomor 1 Juni 2016

Halaman 1-25

http://journal.iaingorontalo.ac.id/index.php/am

\section{SISTEM BAGI HASIL PERTANIAN PADA MASYARAKAT PETANI PENGGARAP DI KABUPATEN GORONTALO PERSPEKTIF HUKUM EKONOMI ISLAM}

\author{
Rizal Darwis \\ Fakultas Syariah IAIN Sultan Amai Gorontalo \\ Email: rizaldarwis@iaingorontalo.ac.id
}

\begin{abstract}
Discourse on the cooperation system of agricultural land in the Islamic jurisprudence has to be specific regulated with a familiar term: muḍarabah, muzāra'ah, musāqah, and mukhābarah. This paper examines the system for the agricultural community in the district of Gorontalo sharecroppers perspective of economics Islamic law. It is a descriptive qualitative research and the data was collected using observation, interviews, and document review. Finding of this study revealed that adapted form of profit sharing land with the agreement of both parties, such as one-half, one-third and one-quarter to see who the provider of seed and operational costs and see nature if crop failure. Implementation of the system for this result is in line with the legal concept of Islamic economics by eliminating injustice to the parties whom to contract it. In addition, these practices have a positive impact for smallholders to raise the level of the economy.
\end{abstract}

Keywords: For Results, Agricultural Land, Sharecroppers, Cooperation

\begin{abstract}
Abstrak
Wacana tentang sistem kerjasama lahan pertanian dalam fikih Islam telah diatur dengan cermat dengan dikenalnya istilah mudarabah, muzāra'ah, musāqah, dan mukhābarah. Tulisan ini mengkaji tentang sistem bagi hasil pertanian pada masyarakat petani penggarap di
\end{abstract}


Kabupaten Gorontalo perspektif hukum ekonomi Islam. Penelitian ini adalah deskriptif kualitatif dengan metode pengumpulan data melalui observasi, wawancara dan dokumentasi. Hasil penelitian menunjukkan bahwa bentuk bagi hasil lahan disesuaikan dengan kesepakatan kedua belah pihak, seperti seperdua, sepertiga dan seperempat dengan melihat siapa penyedia bibit dan biaya operasional serta melihat kondisi alam jika gagal panen. Pelaksanaan sistem bagi hasil ini sejalan dengan konsep hukum ekonomi Islam dengan meniadakan ketidakadilan bagi pihak yang berakad. Selain itu, adanya praktek ini memberikan dampak positif bagi petani penggarap untuk mengangkat taraf perekonomiannya.

\section{Kata Kunci: Bagi Hasil, Lahan Pertanian, Petani Penggarap, Kerjasama}

\section{A. Pendahuluan}

Islam menyeru kepada seluruh kaum muslimin untuk membantu kepada orang yang lemah, memberikan kepada yang membutuhkan, dilarang menindas orang lain, karena menindas orang yang lemah dan meremehkan orang yang membutuhkan pertolongan adalah perbuatanperbuatan yang tidak terpuji, tidak religius, tidak manusiawi dan melanggar norma-norma moral. Islam datang untuk memberikan rasa keadilan dan kesejahteraan bersama dalam menjalani kehidupan di dunia ini.

Islam mengajarkan bagi seorang hamba muslim, hendaknya tidak saling memakan harta di antara sesamamu dengan jalan batil, kecuali dengan jalan perniagaan yang berlaku dengan suka sama suka di antara kamu. ${ }^{1}$ Tidak terkecuali bagi masyarakat petani, khususnya petani penggarap melalui sistem bagi hasil yang umumnya terjadi di pedesaan. Sebagai pekerjaan tambahan untuk menutupi kebutuhan keluarga sebagian masyarakat menyibukkan dirinya dengan kegiatan sebagai petani penggarap. ${ }^{2}$

Hadirnya petani penggarap dalam komunitas petani khususnya di Kabupaten Gorontalo memberi arti penting tidak hanya pada petani di

\footnotetext{
${ }^{1}$ Lihat QS. al-Nisā'/4: 122.

${ }^{2}$ Muhammad Usmān, Al-Rizq al-Halal wa al-Hakikah al-Tawakkal al-Allāh (Kairo: Matahabbah al-Qur'ān, 1972), h. 53.
} 
satu pihak, tetapi juga bagi pemilik lahan di lain pihak yang diuntungkan oleh produktifitas lahan tidurnya. Oleh petani, manfaat diperoleh dari pembagian hasil garapan yang dapat membantu memberikan keuntungan ekonomis atas pendapatan atau penghasilan tersebut, sedangkan pemilik lahan mendapatkan keuntungan ganda dari produktifitas lahan tidur (tidak tergarap), serta dampak ekonomis dari pembagian hasil garapan.

Nabi Muhammad saw. beserta para sahabat beliau pernah mengabulkan permintaan kaumnya untuk bekerjasama dengan sistem bagi hasil pada pengurusan kurma, di mana sebagian kaum bertugas untuk menanam sedang yang lainnya mengurusi hingga membuahkan hasil dan selanjutnya dibagi sesuai kesepakatan. Hal ini didasarkan pada asumsi bahwa perjanjian bagi hasil lebih baik daripada sewa menyewa tanah pertanian, sebab sewa-menyewa tanah pertanian lebih bersifat untung-untungan karena hasil atau produksi tanah sewaan belum secara pasti diketahui kualitasnya, sementara pembayaran/sewa dilunasi terlebih dahulu.

Sistem kemasyarakatan Indonesia sendiri, pola tanam bagi hasil telah dipraktekkan jauh sebelumnya oleh nenek moyang terdahulu, dengan nama dan istilah yang berbeda, antara lain: Maro di Jawa Tengah, Mertelu di Jawa Timur, Nengah atau Jejuron di Jawa Barat, Memperduai di Sumatera Barat, Toyo di Minahasa dan Teseng di Sulawesi Selatan. ${ }^{3}$ Di daerah Gorontalo dikenal dengan istilah mogarapu pangimba lo tau (menggarap sawah orang lain) atau mo balandangia (bisnis modal bersama).

Kabupaten Gorontalo yang terdiri dari 19 Kecamatan, yaitu Asparaga, Dungaliyo, Batudaa, Batudaa Pantai, Bilato, Biluhu, Boliyohuto, Bongomeme, Limboto, Limboto Barat, Mootilango, Pulubala, Tabongo, Telaga, Telaga Biru, Talaga Jaya Tibawa, Tilango, dan Tolango dengan luas lahan pertanian pada tahun 2013 berkisar 13.851.00 hektar ${ }^{4}$ memberikan andil akan adanya praktek bagi hasil

\footnotetext{
${ }^{3}$ Mohammad Daud Ali, Hukum Islam, Pengantar Ilmu Hukum dan Tata Hukum di Indonesia, Ed. 5 (Cet. V; Jakarta: Raja Grafindo Persada, 1996), h. 27.

${ }^{4}$ Kementerian Pertanian, Statistik Lahan Pertanian Tahun 2009-2013, Statistics of Agricultural Land 2009-2013 (Jakarta: Pusat Data dan Informasi Pertanian Sekretariat Jenderal Kementerian Pertanian, 2014), h. 31.
} 
lahan pertanian antara pemilik tanah dan penggarap tanah dalam mekanisme kearifan lokal masyarakat Gorontalo.

Menyangkut pembagian hasil tanah dari bagi hasil, dalam ketentuan Hukum Ekonomi Islam tidak ditemukan petunjuk secara jelas. Maksudnya tidak ditentukan bagaimana cara pembagian dan berapa besar jumlah bagian masing-masing pihak (pemilik tanah dan penggarap). Sayyid Sabiq mengungkapkan, bahwa pemberian hasil untuk orang untuk mengolah atau menanami tanah dari yang dihasilkannya seperti setengah atau sepertiga, atau lebih dari itu, atau pula lebih rendah, sesuai dengan kesepakatan kedua belah pihak (petani dan pemilik tanah). ${ }^{5}$ Dengan demikian tidak ada ketentuan umum yang mengikat antara pemilik tanah dan penggarap untuk selalu tetap berpegang pada ketentuan tersebut. Oleh karena pada prinsipnya bahwa antara kedua belah pihak saling membutuhkan. Pemilik tanah memiliki lahan tetapi tidak mampu memproduktifkannya, dan begitu pula sebaliknya penggarap tidak memiliki lahan tetapi ia berkemampuan untuk memprodutifkannya.

Ada beberapa faktor menjadi penyebab menguaknya kehadiran petani penggarap, antara lain: (a) petani tidak memiliki lahan; (b) bila saja memiliki lahan tetapi tidak mencukupi kebutuhan; (c) pemilik lahan tidak berkemampuan memproduktifkan (mengolah) sendiri; dan (d) pemilik lahan bertempat tinggal jauh dari lahan garapan.

Dalam kaitan ini peneliti merasa perlu mengadakan suatu pendekatan dan atau penelitian ilmiah terhadap praktek penggarapan lahan dengan sistem bagi hasil pada masyarakat petani penggarap di Kabupaten Gorontalo ditinjau dari aspek-aspek sosial masyarakat dan kaidah hukum ekonomi Islam dengan pertimbangan Gorontalo sebagai wilayah mayoritas masyarakatnya beragama Islam, sehingga tentunya berimplikasi bahwa segala aktifitas masyarakatnya selalu didasarkan pada kaidah keislaman.

B. Bagi Hasil dalam Sistem Hukum Ekonomi Syariah

1. Pengertian Bagi Hasil

${ }^{5}$ Sayyid Sabiq, Fiqh Sunnah: Edisi Terjemahan, Jil. IX (Semarang: Toha Putra, 1998), h. 36 . 
Berbagai bentuk dan jenis pertanian dan industri, seni dan kerajinan telah dipraktekkan pada masa Rasulullah saw. Hal itu bukan berarti beliau dalam misinya tidak perlu lagi mengajarkan kepada umat manusia tentang cara-cara berbisnis dalam rangka memenuhi kebutuhan hidup masyarakat. Salah satu bentuk bisnis yang dibolehkan oleh Rasulullah saw. adalah membolehkannya seseorang memproduktifkan tanah bagi pemilik tanah yang tidak mampu memproduktifkan tanahnya dengan perjanjian bagi hasil. Sistem pembagian hasil ini dibenarkan oleh Rasulullah saw. dalam rangka mensejahterahkan umat manusia.

Sejarah mencatat bahwa Rasulullah saw. pernah ikut serta dalam suatu kemitraan usaha dengan Saibin Syarik di Makkah. Kala itu mereka bertemu di Madinah, dia mengingat kejadian tersebut dan menyebutkan bahwa hal tersebut diizinkan oleh Rasulullah saw. ${ }^{6}$ Dalam mendukung syirkah dan muḍārabah ini, diperlukan adanya suatu penekanan atau indikasi ke arah mensejahterahkan umat manusia. Ini dikarenakan sering terjadi seseorang memiliki modal, tetapi tidak mampu menjalankan modal (lahan), atau sebaliknya memiliki kemampuan untuk beruhasa (tenaga), tetapi tidak punya modal (lahan). Oleh karena itu, melalui sistem kerjasama (muḍārabah) ini kedua belah pihak memungkinkan untuk mencapai suatu tujuan dengan jalan saling bekerjasama antara pemiliki modal dan pengelola modal.

Ada beberapa istilah yang perlu dijelaskan kaitannya dengan bentuk kerjasama dalam hukum ekonomi syariah, seperti:

\section{a. Konsep Muḍārabah}

Pengertian secara bahasa, kata muḍarabah atau qiraḍ berasal dari bahasa Arab, yaitu dari kata al-darb berarti bepergian atau berjalan. ${ }^{7}$ Bisa juga diambil dari kata al-qard berarti al-qat' $u$ (potongan). Hal ini dikarenakan pemilik memotong sebagian hartanya untuk diperdagangkan dan memperoleh sebagian keuntungannya. Selain itu ada juga menyebut mudăarabah dengan muamalah. ${ }^{8}$ Kata muḍārabah

\footnotetext{
${ }^{6} \mathrm{M}$. Nejatullah Siddiqi, Partnership and Profit Sharing in Islamic Law, terj. Fakhriyah Mumtihani, Kemitraan Usaha dan Bagi Hasil dalam Hukum Islam, Ed. I (Cet. I; Jakarta: Dana Bhakti Yasa, 1996), h. 6.

${ }^{7}$ Makna ini dapat ditemukan dalam QS al-Muzamil/73: 20.

${ }^{8}$ Abi Bakr ibn Muhammad Taqiyyuddin, Kifayat al-Akhyar (Bandung: Alma'arif, t.th.), h. 301.
} 
biasa dipergunakan oleh penduduk Irak dan kata qirạ̣ atau muqaraḍh dipergunakan oleh penduduk Hijaz. ${ }^{9}$

Ada beberapa pengertian mudāarabah atau qirad menurut istilah yang telah dikemukakan oleh para ulama, seperti:

Menurut Hanafiyah, mudārabah adalah akad antara dua pihak yang berserikat dalam keuntungan (laba), karena harta diserahkan kepada yang lain dan yang lain punya jasa mengelola harta. Menurut Malikiyah, muḍarabah adalah akad perwakilan, di mana pemilik harta mengeluarkan hartanya kepada yang lain untuk diperdagangkan dengan pembayaran yang ditentukan (emas dan perak). Menurut Imam Hanabilah, mudärabah adalah pemilik harta menyerahkan hartanya dengan ukuran tertentu kepada orang yang berdagang dengan bagian dari keuntungan yang diketahui. Menurut Ulama Syafi'iyah, muḍarabah adalah akad yang menentukan seseorang menyerahkan hartanya kepada yang lain untuk ditijarahkan. ${ }^{10}$

Sayyid Sabiq berpendapat pula bahwa mudărabah adalah akad antara dua belah pihak untuk salah satu pihak mengeluarkan sejumlah uang untuk diperdagangkan dengan syarat keuntungan dibagi sesuai dengan perjanjian. ${ }^{11}$ Imam Taqiyuddin mengemukakan pula bahwa muḍārabah adalah akad keuangan untuk dikelola dan dikerjakan dengan perdagangan. ${ }^{12}$

Berdasarkan beberapa pengertian di atas dapat disimpulkan bahwa muḍarabah atau qirad adalah sebuah akad perjanjian antara dua orang atau lebih yang sepakat untuk mengelola harta pihak lain dan keunt ungan dibagi bersama sesuai kesepakatan.

\section{b. Konsep Al-Musāqah}

Al-musāqah diambil dari bahasa Arab, yaitu dari kata al-saqa, artinya seseorang bekerja mengelolah pohon Tamar dan Anggur, atau

\footnotetext{
${ }^{9}$ Hendi Suhendi, Fiqh Muamalah, Ed. 1 (Cet. IX; Jakarta: Rajawali Pers, 2014), h. 135. ${ }^{10}$ Abd al-Raḥmān al-Jazirì, Al-Fiqh 'ala Mazāhib al-'Arba'ah (Bairūt: Dār al-Qalam, t.th.), h. 34-44.

${ }^{11}$ Sayyid Sabiq, Fiqh Sunnah (Bairūt: Dār al-Fikr, 1977), h. 212.

${ }^{12}$ Abi Bakr ibn Muhammad Taqiyuddin, Kifayat al-Akhyar, h. 301.
} 
pohon-pohon lainnya supaya mendatangkan kemaslahatan dan mendapatkan bagian tertentu dari hasil yang diurus sebagai imbalan. ${ }^{13}$

Pengertian menurut istilah dikemukakan oleh beberapa ulama, misalnya ulama fikih, musāqah adalah akad penyerahan kebun (pohonpohonan) kepada petani untuk digarap dengan ketentuan bahwa buahbuahan (hasilnya) dimiliki berdua (pemilik dan petani). ${ }^{14}$

Menurut Malikiyah, al-musāqah adalah sesuatu yang tumbuh. Menurut Syafi'iyah, al-musāqah adalah memberikan pekerjaan orang yang memiliki Tamar dan Anggur kepada orang lain untuk kesenangan keduanya dengan menyiram, memelihara, dan menjaganya, dan pekerja memperoleh bagian tertentu dari buah yang dihasilkan pohon-pohon tersebut. ${ }^{15}$

Menurut Hasbi Ash-Shiddieqi, al-musāqah adalah syarikat pertanian untuk memperoleh hasil dari pepohonan. ${ }^{16}$ Menurut Syaikh Syihab al-Din al-Qalyubi dan Syaikh Umairah, al-musāqah adalah memperkerjakan manusia untuk mengurus pohon dengan menyiram dan memeliharanya serta hasil yang dirizkikan Allah dari pohon itu untuk mereka berdua. ${ }^{17}$

Berdasarkan beberapa pengertian di atas, maka disimpulkan almusāqah adalah sebuah akad antara pemilik pohon dan pekerja untuk memelihara pohon dan pemberian upah diambil dari pohon yang diurusnya.

\section{c. Konsep Al-Muzāra'ah}

Menurut bahasa, al-muzära'ah memiliki dua arti, yaitu tarh alzur'ah (melemparkan tanaman), maksudnya modal (al-hazar). Makna ini

\footnotetext{
${ }^{13}$ Hendi Suhendi, Fiqh Muamalah, h. 145.

${ }^{14}$ M. Ali Hasan, Berbagai Macam Transaksi dalam Islam (Fiqh Muamalat), Ed. 1 (Cet. I; Jakarta: PT RajaGrafindo Persada, 2003), h. 280.

${ }^{15}$ Abd al-Raḥmān al-Jazirì, Al-Fiqh 'ala Maz̄āhib al-'Arba'ah, h. 21-28.

${ }^{16}$ Hasbi Ash-Shiddieqi, Pengantar Fiqh Muamalah (Jakarta: Bulan Bintang, 1984), h. 91.

${ }^{17}$ Syaikh Syihab al-Din al-Qayubi dan Syaikh Umairah, Qalyubi wa Umairah (Indonesia: Dar al-Ihya al-Kutub al-Arabiyah, t.th.), h. 60.
} 
adalah makna majaz. Sedangkan makna yang kedua adalah makna hakiki. ${ }^{18}$

Menurut Hanafiyah, istilah muzāra'ah adalah akad untuk bercocok tanam dengan sebagian yang keluar dari bumi; Menurut Hanabilah, muzāra'ah adalah pemilik tanah yang sebenarnya menyerahkan tanahnya untuk ditanami dan yang bekerja diberi bibit; Menurut Malikiyah, muzāra'ah adalah bersekutu dalam akad atau menjadikan harga sewaan tanah dari uang, hewan, atau barang-barang perdagangan; Menurut Syafi'iyah, muzära'ah adalah seorang pekerja menyewa tanah dengan apa yang dihasilkan dari tanah tersebut; Menurut Ibrahim al-Banjuri, muzāra'ah adalah pekerja mengelola tanah dengan sebagian apa yang dihasilkan darinya dan modal dari pemilik tanah. ${ }^{19}$

Menurut Afzalur Rahman, mengemukakan bahwa muzāra'ah (sistem bagi hasil) adalah sistem kerjasama antara pemilik lahan (tanah) dengan petani penggarap (pekerja) dengan ketentuan pemilik lahan menerima bagian tertentu yang telah ditetapkan dari hasil produksi, bisa $1 / 2$ (setengah), $1 / 3$ (sepertiga) atau $1 / 4$ (seperempat) dari petani penggarap berdasarkan kesepakatan dalam perjanjian dan umumnya pembayaran diberikan dalam bentuk hasil bumi. ${ }^{20}$

Berdasarkan beberapa pengertian di atas diketahui bahwa almuz̄ara'ah adalah akad kerjasama dalam bidang pertanian di mana pemilik tanah memberikan tanahnya kepada pihak pengelola dan bibitnya dari pihak pemilik tanah, serta bagi hasilnya sesuai kesepakatan kedua belah pihak.

\section{d. Konsep Al-Mukhābarah}

Kata al-mukhābarah biasa digunakan oleh orang Irak. ${ }^{21}$ Menurut Syafi'iyah, mukhābarah adalah akad untuk bercocok tanam dengan sebagian apa-apa yang keluar dari bumi, atau menggarap tanah dengan apa yang dikeluarkan dari tanah tersebut; Menurut ulama Hanafiyah, definisi mukhābarah dan muzāra'ah hampir tidak bisa dibedakan.

\footnotetext{
${ }^{18}$ Abd al-Raḥmān al-Jazirī, Al-Fiqh 'ala Mazāhib al- 'Arba'ah, h. 1.

${ }^{19}$ Abd al-Rạ̣mān al-Jazirī, Al-Fiqh 'ala Mazāhib al-'Arba'ah, h. 2-4.

${ }^{20}$ Afzalur Rahman, Economic Doctrines of Islam, terj. Soeroyo dan Nastangin, Doktrin Ekonomi Islam, Jil. II (Cet. III; Jakarta: Dana Bhakti Wakaf, 1995), h. 260-621.

${ }^{21}$ M. Ali Hasan, Berbagai Macam Transaksi, h. 272.
} 
Muzāra'ah menggunakan kalimat aqdun 'alā al-zar'i bi ba'd al-kharij min al-ard (akad untuk bercocok tanam dengan sebagian yang keluar dari bumi), sedangkan dalam mukhäbarah menggunakan kalimat aqdun 'alā al-zar'i bi ba'd ma yakhruju min al-ard (akad untuk bercocok tanam dengan sebagian apa-apa yang keluar dari bumi). Adanya perbedaan redaksi tersebut menunjukkan adanya perbedaan, namun perbedaan tersebut belum diketahui berdasarkan pemikiran Hanafiyah ${ }^{22}$

Al-Rafi'i dan al-Nawawi berpendapat bahwa muzāra'ah dan mukhäbarah memiliki makna yang berbeda. Sedangkan menurut alQadhi Abu Thayib, muzāra'ah dan mukhäbarah merupakan satu pengertian. ${ }^{23}$

Ketika mencermati pengertian antara al-muzära'ah dan almukhäbarah terdapat pengertian yang sama dan pengertian yang berbeda. Persamaanya terletak pemilik tanah menyerahkan tanahnya kepada pihak lain untuk dikelola. Sedangkan perbedaannya pada modal, jika modal berasal dari pemilik tanah disebut muzāra'ah, dan jika modal berasal dari pengelola disebut al-mukhābarah.

Secara sederhana dapat dikemukakan bahwa yang dimaksud dengan sistem bagi hasil adalah perjanjian pengolahan tanah, dengan upah sebagian dari hasil yang diperoleh dari pengolahan tanah itu. ${ }^{24}$ Ahli lain memberikan definisi bahwa yang dimaksud dengan sistem bagi hasil disebutnya mudāarabah, yaitu satu pihak menyediakan modal dan pihak lain memanfaatkannya untuk tujuan-tujuan usaha, berdasarkan kesepakatan bahwa keuntungan dari usaha tersebut akan dibagi menurut bagian yang ditentukan. ${ }^{25}$

Bertitik tolak dari beberapa pandangan yang dikemukakan di atas, dapat disimpulkan bahwa yang dimaksud dengan bagi hasil adalah pembagian keuntungan dari hasil usaha (kebun/tanah) antara pekerja (petani penggarap) dengan pemodal (pemilik lahan) karena pemilik lahan tidak memiliki kemampuan memproduktifkan lahannya, sehingga

\footnotetext{
${ }^{22}$ Abd al-Raḥmān al-Jazirī, Al-Fiqh 'ala Maz̄āhib al- 'Arba'ah, h. 2-4.

${ }^{23}$ Abi Bakr ibn Muhammad Taqiyuddin, Kifayat al-Akhyar, h. 153.

${ }^{24}$ Chairuman Pasaribu dan Suhrawardi K. Lubis, Hukum Perjanjian Dalam Islam (Cet. II; Jakarta: Sinar Grafika, 1996), h. 61.

${ }^{25}$ M. Nejatullah Siddiqi, Partnership and Profit Sharing in Islamic Law, terj. Fakhriyah Mumtihani, Kemitraan Usaha, h. 8.
} 
ia memberikan lahannya kepada orang lain untuk diproduktifkan dengan ketentuan bagi hasil atau muḍarabah.

\section{Bentuk dan Jenis Bagi Hasil}

Setiap perubahan dari satu pola ke pola hidup yang lain atau perubahan peradaban menuju peradaban yang baru, memerlukan adanya penyesuaian dalam institusi dan berbagai cara hidup secara menyeluruh. Dengan kata lain, keinginan untuk mencapai perubahan dalam kehidupan, semua pendekatan yang sesuai dan memiliki relevansi dengan pola tingkah laku manusia-ekonomi, politik, sosial dan rohani, seharusnya dilaksanakan secara maksimal. Perubahan yang dimaksud di atas adalah adalah peralihan budaya materi menuju budaya Islam dan dapat terwujud dalam kerjasama dalam kehidupan ekonomi, khususnya kerjasama bidang pertanian.

Kaitannya dengan kerjasama dalam bidang pertanian (lahan tanah persawahan). Pengolahan tanah dapat dilakukan dengan dua bentuk, yaitu: Pertama, pemilik tanah bisa mengolahnya sendiri dan berkuasa atas tanah dan hasilnya. Kedua, bisa dengan menyerahkan kepada orang lain untuk digarap, yaitu petani membayar langsung atas penggunaan tanah tersebut atau membagi hasil dengannya.

Semua bentuk sistem bagi hasil yang dapat menyebabkan terjadinya kerjasama dan terwujudnya persatuan dan persaudaraan antara penggarap dan pemilik tanah dan jauh dari kemungkinan terjadinya perpecahan antara keduanya dibenarkan Islam. Sebaliknya semua bentuk sistem bagi hasil yang dapat menyebabkan timbulnya perselisihan di kalangan masyarakat atau mengganggu hak dari pihak tertentu dinyatakan tidak sah oleh Islam. Sebagaimana yang pernah terjadi pada masa Rasulullah saw., di mana tiga orang sahabat yang terkenal sebagai petani pada masa Rasulullah saw. meriwayatkan bahwa bentuk sistem bagi hasil yang mendorong seseorang untuk senantiasa hidup di atas keringat orang lain, dan melanggar hak-hak keadilan terhadap petani sangat dibenci oleh Rasulullah saw. ${ }^{26}$

Melalui sistem muzāra'ah atau sistem bagi hasil kedua belah pihak memungkinkan mencapai suatu tujuan, di samping mewujudkan ta'awwun atau saling tolong menolong yang menyebabkan kedua belah

\footnotetext{
${ }^{26}$ Afzalur Rahman, Economic Doctrines of Islam, terj. Soeroyo dan Nastangin, h. 270.
} 
pihak memperoleh keuntungan dari hasil usaha yang dilakukan oleh pekerja (petani penggarap). Dalam hal ini pekerja (petani penggarap) menggarap lahan seseorang karena kemampuannya untuk menggarap ada, sementara lahan tidak dimilikinya. Sebaliknya ada orang yang punya lahan, namun tidak memiliki kemampuan untuk menggarapnya.

Sebagaimana dijelaskan dalam fikih Islam, ada tiga istilah untuk membicarakan hal pembagian hasil suatu kebun yang digarap atau diurus dua orang atau lebih, sedang salah satunya merupakan pemilik kebun (tanah). Istilah tersebut adalah musāqah, muzāra'ah dan ketiga adalah mukhabarah. ${ }^{27}$

Uraian singkat tersebut menunjukkan bahwa bentuk dan jenis pengelolaan kebun adalah musāqah, muzära'ah dan mukhābarah. Adapun musāqah adalah seorang pemilik kebun menyerahkan pengurusan kebunnya pada seorang tukang kebun atau petani dan bagi hasil. Adapun muzāra'ah adalah semacam paruhan mirip musāqah tetapi benih maupun biaya-biaya yang berkenaan dengan tanamkan itu kepunyaan penggarap satu-satunya dari pemilik adalah tanah (kebun)nya. Sedangkan mukhābarah adalah semacam muzāra'ah tetapi benih diusahakan oleh si pemilik tanah, sedang penggarap hanya garapannya saja. $^{28}$

Jika dianalisa bentuk ketiga pengolahan tanah di atas tergambar bahwa bentuk dan jenis sistem bagi hasil pun mengikuti ketiga bentuk pengolahan tanah tersebut. Sebagai contoh, bentuk pertama: pengolahan tanah (kebun/sawah) menerapkan sistem musāqah di mana pemilik tanah (kebun/sawah) bekerjasama segala-galanya dengan penggarap. Artinya bahwa segala hal yang berkenaan pengurusan kebun/sawah, baik benih, pupuk dan lain-lainnya ditanggung bersama antara pemilik dan penggarap, maka jenis bagi hasil ini termasuk bentuk 50:50 atau bagi dua antara penggarap dengan pemilik tanah atau kebun.

Bentuk kedua, yakni sistem muzāra'ah, di mana benih yang ditanam serta keperluan lainnya berupa pupuk dan lainnya itu ditanggung penggarap, dan bagi pemilik kebun/sawh hanya menanggung lahan (kebunnya), maka hasil produksinya harus dibagi separoh misalnya

\footnotetext{
${ }^{27}$ Hasbullah Bakry, Pedoman Islam Indonesia (Cet. V; Jakarta: UI Press, 1990), h. 284285.

${ }^{28}$ Hasbullah Bakry, Pedoman Islam Indonesia, h. 284-285.
} 
(sepertiga) $1 / 3$ untuk pemilik kebun dan (duapertiga) $2 / 3$ untuk penggarap kebun. Dan ketiga adalah bentuk mukhäbarah, yakni kebalikan dengan sistem muzāra'ah. Bentuk mukhäbarah ini segala yang berkenan dengan kebun dan benihnya ditanggung sepenuhnya oleh pemilik tanah dan petani penggarapnya hanya menggarap saja. Maka jenis dan bentuk bagi hasilnyapun hendaknya berbalik, yakni penggarap dapat sepertiga $(1 / 3)$ dan pemilik kebun mendapat bagian dua pertiga $(2 / 3)$, dan ketiga bentuk dan jenis bagi hasil itupun harus sesuai dengan kesepakatan kedua belah pihak yakni penggarap dan pemilik kebun.

Untuk situasi umat Islam sepanjang masa dapat ditiru kebolehan persetujuan tersebut mengingat terdapatnya pemilik lahan/kebun/sawah yang tidak punya waktu untuk menggarap kebun/ladang/sawahnya, sebaliknya di pihak lain ada orang yang punya kesempatan luang dan kemampuan untuk mengolah lahan/ladang/sawah, tetapi tidak memiliki ladang lahan/kebun/sawah untuk digarapnya. Intinya yang terpenting bagi keduanya adalah adanya perjanjian yang disepakati sebelumnya, agar kedua belah pihak dapat meminimalisir terjadinya persengketaan setelah tiba masanya pembagian hasil produksi pertanian.

Pembagian hasil kepada pihak penggarap bervariatif, yakni sesuai dengan adat kebiasaan yang berkembang di tengah-tengah masyarakat, ada yang setengah, sepertiga, atau lebih rendah dari itu. Namun yang tidak kalah pentingnya dalam tiga bentuk dan jenis pengolahan kebun/ladang/sawah tersebut adalah terjalinnya kesepahaman atau kesepakatan antara petani penggarap dengan pemilik lahan/kebun/sawah.

Dalam ajaran Islam menganjurkan agar hasil kesepahaman atau kesepakatan yang telah menjadi perjanjian keduanya hendaknya ditulis agar tidak mudah dilupakan atau dikhianati. Hal ini diterangkan dalam QS al-Baqarah/2: 282.

Secara tekstual ayat tersebut menyebutkan hutang piutang, namun dalam hal hubungan interaksi manusia dengan manusia yang mengandung adanya unsur hak dan kewajiban maka menjadi keharusan untuk ditulis dan disaksikan oleh dua orang laki-laki atau seorang lelaki dan dua orang perempuan. Hal ini dimaksudkan agar perjanjian yang telah disepakati itu tidak mudah dilupakan, sebab bila seorang lupa, yang lainnya (saksi lain) masih ingat. 


\section{Praktek Bagi Hasil Pertanian di Kabupaten Gorontalo}

Dalam fikih Islam terkenal istilah dalam proses pengurusan kebun/lahan, yaitu musāqah, muzāra'ah, mukhābarah dan mugarasah. Untuk membicarakan hal pembagian hasil suatu kebun yang digarap atau diurus oleh dua orang atau lebih, sedang salah satu pihak merupakan pemilik kebun tersebut.

Pemberian kebun/lahan/sawah terhadap orang lain seperti yang dipraktekkan oleh masyarakat di Kabupaten Gorontalo merupakan suatu kegiatan yang dapat menciptakan kerukunan antar masyarakat, menimbulkan rasa solidaritas antar sesama warga, dan menumbuh suburkan sifat tolong menolong di kalangan masyarakat muslim Gorontalo, walaupun pemberian lahan atau kebun tersebut tidak dengan cuma-cuma melainkan dengan sistem kerjasama dengan bagi hasil. Dalam salah satu hadis Rasulullah saw. dijelaskan bahwa:

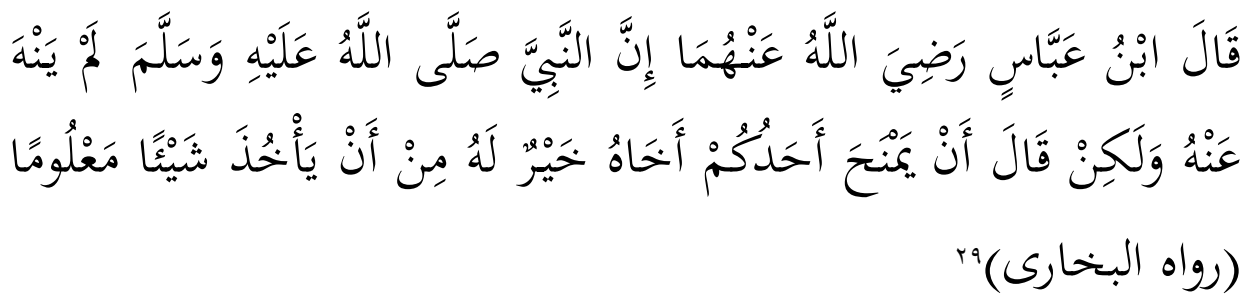

Artinya: Ibn Abbās ra. berkata bahwa sesungguhnya Nabi saw. belum melarang kepadanya, namun telah bersabda: apabila tanah tersebut tidak akan kau berikan kepada saudaramu dengan cuma-cuma atau membiarkan terbengkalai (tidak terolah), lebih baik kamu menyerahkannya untuk diolah yang ditukar dengan sewa tetap (bagi hasil) (HR al-Bukhārī).

Pembagian hasil seperti itu selain diungkapkan dalam hadis di atas, juga terdapat salah satu hadis Nabi saw. yaitu:

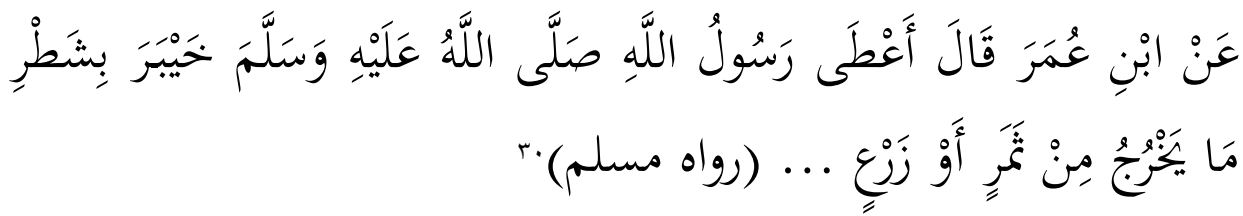

\footnotetext{
${ }^{29} \mathrm{Abi}$ 'Abdillah Muhammad bin Ismā'il bin Ibrāhim bin al-Mugirah bin Barẓabah alBukhārì, Sahịḥ al-Bukhārī, Juz 8 (Bairūt: Dār al-Kutub al-'Ilmiyyah, 1992 M/1412 H), h. 153.
} 
Artinya: Dari Ibn Umar berkata bahwa Rasulullah saw. telah memberikan kebun beliau kepada penduduk Khaibar, agar dipelihara oleh mereka dengan perjanjian, kepada mereka diberikan sebagian dari hasil kebun tersebut atau sayur-mayur(HR Muslim).

Hadis ini menurut hemat penulis, memberikan kebolehan persetujuan mengingat ada pemilik kebun yang tidak punya waktu untuk menggarap kebun atau ladangnya, sedangkan sebaliknya ada pekerja yang cukup waktu luang untuk mengurus sebuah kebun tetapi ia tidak mempunyai kebun atau lahan.

Sistem kerjasama bagi hasil hendaknya dilakukan dengan cara mengadakan permufakatan atau perjanjian antara kedua belah pihak yakni pihak pemilik kebun dan pihak pengelola. Hal ini sangat penting dilakukan dalam kerangka menghindari terjadinya hal-hal yang tidak diinginkan oleh kedua pihak yakni pertikaian atau perselisihan, walaupun perjanjian itu berupa lisan dan dianjurkan perjanjiannya itu tertulis.

Salah satu batu sandungan tidak dibolehkannya sistem kerjasama bagi hasil adalah menghindari terjadinya perselisihan, sehingga perpecahan di antara kaum muslimin dapat pecah. Karena pertimbangan itulah, sehingga semua bentuk sistem bagi hasil yang dapat menyebabkan timbulnya perselisihan di kalangan masyarakat atau mengganggu pihak tertentu dinyatakan tidak sah. ${ }^{31}$

Sebagaimana dikemukakan sebelumnya bahwa terjadinya sistem bagi hasil pertanian ini adalah karena terdapat di kalangan masyarakat seorang yang memiliki lahan perkebunan, tetapi ia tidak sanggup menggarap atau mengolahnya, sehingga kebun atau lahannya tidak terurus. Sebaliknya, terdapat pula orang yang sanggup dan punya waktu luang untuk menggarap tanah, tetapi ia tidak mempunyai tanah atau lahan. Langkah ini tidak ditemukan adanya peraturan dalam syariah yang melarang setiap orang untuk menanamkan modal berupa dana ataupun tenaga secara patungan untuk memulai satu kerjasama bagi

\footnotetext{
${ }^{30}$ Imām Muslim ibn al-Hajāj al-Qusyairī al-Naisaburī, Ṣaḥịh Muslim, Juz 8 (Bairūt: Dār al-Kutub al-'Ilmiyah, t.th.), h. 172.

${ }^{31}$ Afzalur Rahman, Economic Doctrines of Islam, terj. Soeroyo dan Nastangin, Doktrin Ekonomi Islam, h. 270.
} 
hasil pertanian, ${ }^{32}$ kecuali jika kegiatan itu menimbulkan perselisihan antara kedua belah pihak.

Salah satu ilustrasi yang digambarkan oleh Rasulullah saw. menunjukkan bahwa dahulu di zaman beliau, ada tiga orang sahabat yang terkenal sebagai petani, yaitu: Rafi'i bin Khadij, Jabir bin Abdullah dan Thabat bin Zahhak dan meriwayatkan bahwasanya Nabi saw. melarang bentuk-bentuk persewaan yang dzalim. ${ }^{33}$ Apabila sudah menyerahkan kebun atau lahannya kepada seorang petani penggarap untuk ditanaminya, dan pemilik kebun atau lahan itu menetapkan bagian yang jelas diketahui dari hasil kebun atau lahan, maka cara semacam itu tidak dibolehkan. ${ }^{34}$

Paradigma tersebut menunjukkan bahwa secara syar'i praktek bagi hasil yang diterapkan oleh masyarakat petani beserta para pemilik kebun/lahan/sawah di Kabupaten Gorontalo tampaknya relevan dengan syariat Islam, di mana Islam mensyariatkan dan membolehkan untuk memberi keringanan kepada manusia, karena terkadang ada manusia yang tidak mempunyai harta cukup untuk memenuhi kebutuhan hidupnya. Sementara ada pula orang lain yang mempunyai harta banyak sehingga sebagian dari hartanya itu tidak mampu diurusnya. Misalnya berupa kebun atau lahan yang sudah tidak terurus, daripada tidak berproduksi akan lebih baik jika lahan tersebut diberikan orang lain mengurusnya dengan jaminan atau perjanjian bagi hasil.

Menurut Arwin S. Hilala bahwa sistem bagi hasil yang diterapkan di Gorontalo, khususnya di Desa Lupoyo adalah sistem bagi hasil secara koperasi, artinya bahwa antara pemilik lahan atau kebun dan petani penggarap menetapkan pembagian berdasarkan untung-rugi, yakni pembagiannya tidak jelas (nyata) melainkan bergantung pada hasil panen dari lahan atau kebun setelah dikeluarkan seluruh biaya yang telah digunakan selama proses pengurusannya. Jadi kedua belah pihak samasama saling mengerti sesuai dengan kesepakatan sebelumnya. Kalau

\footnotetext{
${ }^{32}$ M. Nejatullah Siddiqi, Partnership and Profit Sharing in Islamic Law, terj. Fakhriyah Mumtihani, Kemitraan Usaha, h. 113.

${ }^{33}$ Afzalur Rahman, Economic Doctrines of Islam, terj. Soeroyo dan Nastangin, Doktrin Ekonomi Islam, h. 270.

${ }^{34}$ Al-Allamah Syekh Muhammad bin Qasim, Fath al-Qarib, terj. H. Abubakar Muhammad, Fiqih Islam (Terjemah Fath al Qarib) (Surabaya: Karya Abitama, 1995), h. 181 .
} 
gagal panen maka keduanya pun rela menerima kegagalan itu, dan jika berhasil panen maka keduanya pula akan membaginya melalui sistem bagi hasil. ${ }^{35}$

Di lain pihak menurut Katili Ibrahim menjelaskan bahwa pembagian bagi hasil bagi petani penggarap adalah $25 \mathrm{~kg}$ beras untuk sekali panen, di mana bibit dan biaya pengolahan lahan sawah sepenuhnya ditanggung oleh petani penggarap. ${ }^{36}$

Jika mencermati dua pandangan di atas ada dua perbedaan yang cukup mencolok di mana Arwin S. Hilala menerangkan bahwa bagi hasil lahan pertanian disesuaikan dengan kesepakatan dan adanya faktor alam yang mendukung, artinya kalo panen gagal maka mereka membagi kerugian dan keuntungan bersama-sama. Sedangkan menurut Katili Ibrahim bisa berindikasi terhadap adanya ketidakadilan dalam penerapan bagi hasil, di mana kalau panennya sukses dan berlimpah, pihak pemilik tanah hanya mendapat $25 \mathrm{~kg}$ saja dalam sekali panen.

Adanya praktek bagi hasil pertanian untuk pemilik kebun atau lahan hendaknya tidak menetapkan secara jelas bagian yang akan diambilnya kelak, sebab petani terkadang gagal panen. Penetapan jelas yang dimaksud adalah antara lain, menetapkan angka pasti 40 liter kacang tanah harus diterimanya, tetapi karena gagal panen maka hasil panennya hanya berkisar 20 liter, sementara si pemilik tidak mau tahu kegagalan panen itu. Oleh karenanya, petani penggarap itulah yang harus menutupi kekurangan panen itu. Hal ini sangat ditekankan dalam hukum Islam bahwa meniadakan kecurangan dan kezaliman dalam bermuamalah.

Penetapan sistem bagi hasil secara jelas sebagaimana dikemukakan di atas, jelas dapat menimbulkan perselisihan dan dapat merugikan orang lain yakni petani penggarap. Oleh karena itu, sistem bagi hasil yang disertai dengan pembagian secara jelas sama sekali tidak pernah dipraktekkan oleh para sahabat di zaman Nabi, dan karenanya dapat dikatakan bertentangan dengan syari' at Islam.

\footnotetext{
${ }^{35}$ Arwin S. Hilala, Petani Penggarap, Wawancara di Desa Lupoyo Kabupaten Gorontalo, tanggal 12 Nopember 2016.

${ }^{36}$ Katili Ibrahim, Petani Penggarap, Wawancara di Desa Dumiati Kabupaten Gorontalo, tanggal 12 Nopember 2016.
} 
Dengan demikian, sistem bagi hasil oleh masyarakat muslim di Kabupaten Gorontalo masih terdapat dua jenis praktek. Praktek pertama sesuai dengan syariat karena adanya kesadaran mereka akan terciptanya suasana yang aman, sejahtera dan bahagia sehingga prinsip hidup mereka senantiasa berlandaskan dengan nilai-nilai keislaman termasuk dalam praktek pengelolaan lahan atau kebun dengan sistem bagi hasil. Sedangkan praktek kedua masih mengadung ketidakadilan.

Islam sebagai agama, hudan li al-nās, memberikan pedoman bagi seluruh umat manusia, universal, meliputi seluruh aspek kehidupan sesuai untuk segala zaman dan tempat. Di samping itu, agama juga mengajak kepada kesempurnaan hidup lahir dan batin, bahagia hidup di dunia dan akhirat. Umat muslim sebagai khalifah di bumi ini wajib mengamalkan ajaran Islam dalam tingkah laku konkrit, nyata yakni amalan shalih ke dalam berbagai sektor kehidupan termasuk sektor ekonomi.

Semua sub sektor ekonomi misalnya pemasaran dan konsumsi, produksi, industri dan jasa, termasuk pula produksi pertanian harus berpedoman pada asas dan peraturan Alqur'an dan hadis. Begitu pula kelembagaan ekonominya dan pelaku ekonominya termasuk dalam hal ini pemilik tanah dan petani penggarap harus bertolak dari nilai-nilai Islam, apabila ingin mencapai keuntungan dunia akhirat. Oleh karena itu, penerapan sistem bagi hasil dalam sistem pertanian (pengolahan kebun) harus benar-benar mencerminkan nilai-nilai kemanusiaan yang berlandaskan pada asas Islami.

Implementasi dan pelaksanaan sistem bagi hasil sebagaimana yang dipraktekkan oleh masyarakat Kabupaten Gorontalo merupakan sistem bagi hasil yang memungkinkan terhindar dari terjadinya perselisihan. Hal itu disebabkan karena sebelum terjadi kerjasama terlebih dahulu mereka mengadakan perjanjian di antara keduanya, hanya saja karena perjanjian tersebut sebagian dari mereka ada yang masih bersifat lisan dan ada pula yang sudah tertulis. Bagi mereka yang perjanjiannya bersifat lisan, menurut Arifin Yusuf dilakukan atas saling kepercayaan antara satu sama lain. ${ }^{37}$

\footnotetext{
${ }^{37}$ Arifin Yusuf, Petani Penggarap, Wawancara di Desa Tuladenggi Kabupaten Gorontalo, tanggal 12 Nopember 2016.
} 
Terjadinya perselisihan pada kegiatan pertanian khususnya bagi petani penggarap dan pemilik kebun, pada umumnya disebabkan atas adanya mosi tidak percaya pada petani penggarap terutama berkenaan dengan biaya yang dibutuhkan dalam pengurusan kebun serta hasil produksi pertanian yang diperoleh dalam setiap kali panen sehingga timbul kecurigaan pada diri petani penggarap.

Argumentasi di atas menunjukkan betapa pentingnya rasa saling percaya mempercayai antara petani penggarap dan pemilik lahan atau kebun. Salah satu cara untuk menciptakan terjadinya saling kepercayaan adalah membuat perjanjian (sebaiknya tertulis) disertai dengan saksisaksi dengan mengikutsertakan sistem pembagian hasil produksi. Praktek pembagian hasil produksi pertanian ini, telah lama dipraktekkan oleh masyarakat di Kabupaten Gorontalo.

Para pemilik lahan atau kebun yang mempekerjakan orang lain (petani penggarap) menurut Jimadi Hasan pemilik lahan ketika diwawancarai penulis bahwa "rata-rata mereka menerapkan sistem bagi hasil yakni sepertiga untuk pemilik dan dua pertiga untuk petani penggarap". ${ }^{38}$ Demikian pula menurut Inang Igrisa ketika diwawancarai penulis mengemukakan bahwa "saya sebagai petani penggarap senang atas sistem bagi hasil yang diterapkan oleh pemilik lahan atau kebun yang saya garap, yakni sepertiga untuk pemilik dan dua pertiga untuk penggarap."39

Bentuk penerapan sistem bagi dalam syariat Islam secara jelas dan nyata tidak ditemukan. Sebagaimana Chairuman Pasaribu dan Suhrawardi K. Lubis mengemukakan bahwa menyangkut pembagian hasil tanah dari perjanjian bagi hasil dalam ketentuan syariat Islam tidak ditemukan petunjuk yang jelas. ${ }^{40}$ Pemberian hasil untuk orang yang mengolah atau menanami tanah dari yang dihasilkannya seperti setengah, sepertiga, atau lebih dari itu ataupun lebih rendah dari kesepakatan kedua belah pihak (petani dan pemilik tanah), sebagaimana yang diterapkan oleh para pemilik lahan atau kebun dan petani

\footnotetext{
${ }^{38}$ Jimadi Hasan, Pemilik Lahan, Wawancara di Desa Lupoyo Kabupaten Gorontalo, tanggal 13 Nopember 2016.

${ }^{39}$ Inang Igrisa, Petani Penggarap, Wawancara di Desa Tuladenggi Kabupaten Gorontalo, tanggal 13 Nopember 2016.

${ }^{40}$ Chairuman Pasaribu dan Suhrawardi K. Lubis, Hukum Perjanjian Dalam Islam, h. 6364.
} 
penggarap di Kabupaten Gorontalo selama perjanjian dan kerjasama mereka tidak menimbulkan perselisihan di antara keduanya maka penulis cenderung memandang bahwa hal itu sejalan dengan syariat Islam.

Sistem bagi hasil jika ditinjau dari manfaatnya, cukup besar bagi kalangan mereka, yakni pemilik lahan atau kebun maupun bagi petani penggarap. Manfaatnya selain menambah penghasilan kedua belah pihak, memberikan sebagian nafkah kepada orang lain juga menciptakan saling kerjasama, tolong menolong dan mempererat jalinan ukhuwah di antara mereka.

Dalam ajaran Alquran, upaya menafkahkan sebagian harta kepada orang lain, tidak ditentukan bentuk dan jenisnya. Oleh karena itu, memberikan lahan atau kebun kepada orang lain diolah dan digarap termasuk salah bentuk menafkahkan harta kepada orang lain. Salah satu dalil yang menunjang tentang tidak adanya bentuk yang jelas atas membelanjakan sebagian harta adalah QS Ali Imran/3: 92:

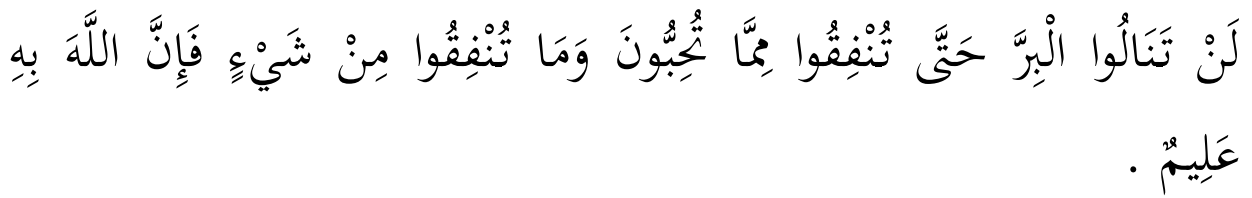

Terjemahnya: Kamu sekali-kali tidak sampai kepada kebajikan (yang sempurna), sebelum kamu menafkahkan sebahagian harta yang kamu cintai. ${ }^{41}$

Di ayat lain yaitu QS al-Baqarah/2: 148 disebutkan bahwa:

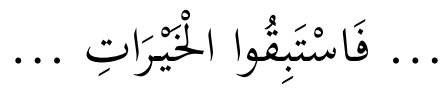

Terjemahnya: ... maka berlomba-lombalah kamu dalam kebaikan .... ${ }^{42}$

Bertolak dari kedua ayat di atas, menggambarkan bahwa salah satu cara untuk menafkahkan sebagian harta sekaligus berlomba dalam mencari keridhaan dan kebaikan adalah mempekerjakan orang lain, termasuk dalam pengolahan lahan atau kebun. Sebab bagi mereka

\footnotetext{
${ }^{41}$ Kementerian Agama RI., Ummul Mukminin: Al-Qur'an dan Terjemah Untuk Wanita (Jakarta Selatan: Penerbit Wali, 2010), h. 62.

${ }^{42}$ Kementerian Agama RI., Ummul Mukminin: Al-Qur'an dan Terjemah, h. 23.
} 
bekerja sebagai bertani walaupun lahannya milik orang lain, merupakan suatu pekerjaan mulia. Dan berkebun jauh lebih baik dari pada mencuri atau meminta-minta seperti yang terjadi di kota-kota.

Jafar Husain mengemukakan bahwa penerapan sistem bagi hasil yang diterapkan oleh para pemilik lahan terhadap petani penggarap di Kabupaten Gorontalo seperti sepertiga untuk pemilik lahan atau kebun dan dua pertiga untuk penggarap, atau sebaliknya sepertiga untuk penggarap dan dua pertiga untuk pemilik tanah. Persetujuan ini mereka terapkan sesuai dengan persepakatannya pula. Oleh karena itu, jika seluruh dana yang dibutuhkan dalam proses pengolahan kebun ditanggung oleh pemilik kebun, maka pembagian dilakukan dua pertiga untuk pemilik kebun dan sepertiga untuk penggarap, tetapi sebaliknya jika seluruh biaya pengurusan kebun ditanggung oleh petani penggarap maka pembagian hasil produksinya dua pertiga untuk petani penggarap dan sepertiga untuk pemilik lahan. ${ }^{43}$

Bentuk pengolahan lahan yang diterapkan masyarakat Kabupaten Gorontalo merupakan suatu cara menumbuhkan kebajikan dan rasa simpati di hati manusia. Kenyataan diakui bahwa tindakan yang paling baik yaitu dengan murah hati dan penuh kedermawanan memberikan kelebihan tanah yang dimilikinya untuk digarap orang lain. Dengan demikian, sistem bagi hasil yang dipraktekkan selama ini dapat dikategorikan sebagai suatu sistem yang dapat menguntungkan satu sama lainnya. Berusaha untuk berbuat baik kepada orang lain, lebih mengutamakan kepentingan orang lain di atas kepentingan pribadi, mengorbankan sesuatu yang paling dicintai seseorang bahkan sesuatu yang paling mahal sekalipun sebagai wujud perbuatan atau amal dan memperluas tali silaturrahmi. Singkatnya, kualitas sikap semacam itu tumbuh di kalangan masyarakat sehingga mereka senantiasa bersedia melakukan kebaikan-kebaikan bahkan mungkin berkorban untuk orang lain jika dibutuhkan.

Sistem bagi hasil yang merupakan suatu jenis perjanjian dimana petani menerima tanah berdasarkan sistem bagi hasil, pemilik tanah membayarnya sebagai upah atas kerjanya berupa hasil produksi. Demikian pula petani membayar sewa kepada pemilik tanah dalam

\footnotetext{
${ }^{43}$ Jafar Husain, Pemilik Lahan, Wawancara di Desa Lupoyo Kabupaten Gorontalo, tanggal 13 Nopember 2016.
} 
bentuk hasil produksi. Jika terkandung nilai kebajikan dan kedermawanan dibalik perjanjian ini dan tidak semata-mata hanya berharap menerima behagian atas tanahnya atau tenaga yang dikeluarkannya, maka penulis melihatnya sebagai bentuk kerjasama, persaudaraan dan persahabatan yang paling baik. Akan tetapi jika sebaliknya, semangat seperti itu kurang atau lemah serta petani yang tidak berdaya menjadi alat penindasan dan eksploitasi dari pemilik tanah, atau adanya ketakutan terhadap ketidakjujuran berbagai pihak atau terdapat kemungkinan perselisihan-perselisihan di antara mereka, maka bentuk semacam inilah yang sangat dilarang oleh syariat Islam.

\section{Dampak Bagi Hasil pada Aspek Ekonomi Petani Penggarap di Kabupaten Gorontalo}

Meskipun produksi pertanian dalam zaman modern ini telah beralih menjadi satu industri. Masih terdapat sejumlah literatur hukum tentang prinsip-prinsip dan hukum kemitraan usaha dan hubungan kerjasa sama, dalam pembagian hasil pertanian dan musāqat, antara pemilik lahan atau kebun dan petani penggarap dalam perusahaanperusahaan pertanian. Sistem bagi hasil antara kedua belah pihak yakni pemilik kebun dan petani penggarap yang di dalamnya terdapat perjanjian bagi hasil secara adil menurut kesepakatan bersama antara petani penggarap dan pemilik kebun.

Apabila seorang pemilik lahan bekerja sama dengan orang lain atau bekerja sama dengan seorang mitra usaha pekerja yakni petani penggarap, maka hendaknyalah didahului perjanjian yang dengan perjanjian itu keduanya dapat terhindar dari perselisihan. Hal ini sangat urgen dilakukan oleh pihak pengelola lahan dan pemilik lahan demi menghindari dampak-dampak negatif yang mungkin terjadi.

Pada dasarnya, petani penggarap dalam mengelola lahan orang lain disebabkan dua hal, yakni pertama memiliki lahan tetapi belum mencukupi kebutuhan hidup keluarganya dan kedua adalah karena memang tidak memiliki lahan dan tidak memiliki lapangan pekerjaan lain (keterampilan) selain bertani. Oleh karenanya, mereka inilah mengadakan negosiasi dengan tetangganya yang memiliki kelebihan lahan atau mereka yang memiliki lahan tetapi tidak terolah, lalu kemudian diolahnya dengan sistem bagi hasil. 
Aktivitas pertanian mereka lakukan dalam rangka meningkatkan perekonomian keluarganya. Bahkan bagi mereka yang tidak memiliki lahan sama sekali, tidak hanya mencukupi kebutuhan hidup keluarga tetapi memenuhi kebutuhan keluarga. Sebagai hamba yang lahir tanpa bekal apa-apa kecuali akal, dalam memenuhi kelangsungan hidup dan masa depan sudah barang tentu tidak terlepas dari upaya memanfaatkan akal pikiran guna mencari suatu alternatif untuk memiliki rutinitas dalam usaha mempertahankan kelangsungan hidup. Termasuk petani penggarap dalam komunitas petani khususnya di Kabupaten Gorontalo memberi arti penting tidak hanya bagi dirinya sendiri. Tetapi juga terhadap pemilik lahan atau kebun yang diuntungkan oleh produktifitas lahan tidurnya.

Manfaat yang diperoleh petani penggarap diperoleh dari pembagian hasil garapan yang dapat membantu memberikan keuntungan ekonomi demi memenuhi kebutuhan hidupnya, sedangkan bagi pemilik lahan mendapat keuntungan ganda dari produksi lahannya, yakni di samping memberikan penghasilan tambahan, juga melakukan amal shaleh secara tidak langsung dengan cara menolong petani penggarap untuk menutupi kebutuhan dan keperluan hidupnya.

Menurut Yunus Kulu ketika diwawancarai penulis mengemukakan bahwa dampak bagi hasil terhadap aspek ekonomi petani penggarap seperti saya rasakan selama ini dapat meningkatkan pendapatan atau penghasilan keluarga, sebab di samping menggarap milik sendiri karena ada sedikit, saya juga meminta lahan orang atau teman untuk digarap karena lahan tersebut kebetulan tidak terurus (tidur), daripada lahannya tidak berporduksi mendingan saya yang garap kemudian produksinya nanti diterapkan sistem bagi hasil setelah dikeluarkan biaya yang dibutuhkan dalam proses pengolahan kebun. ${ }^{44}$

Hal senada diungkapkan oleh Ali Bilondatu bahwa petani penggarap seperti kita ini yang mengelola lawah orang lain dengan harapan mendapatkan bagian dari hasil produksi lahan yang dikelola setelah dikeluarkan seluruh biaya yang dibutuhkan selama pengelolaan kebun. Karena biaya yang dibutuhkan itu seluruhnya ditanggung oleh pemilik tanah, sebab saya termasuk berada di bawah garis kemiskinan.

\footnotetext{
${ }^{44}$ Yunus Kulu, Petani Penggarap, Wawancara di Desa Pentadio Kabupaten Gorontalo, tanggal 13 Nopember 2016.
} 
Oleh karena itu, jika telah sampai panen pemilik lahan yang membagi dua untuk pemilik dan satu untuk saya. Tetapi karena pemilik lahan termasuk orang yang mampu dan suka bersedekah, biasa juga hasil produksi kebunnya lebih banyak dia berikan kepada saya. Karena itu, saya betul-betul garap kebun tersebut secara baik dan seperti milik sendiri." 45

Dari informasi yang dikemukakan di atas menunjukkan bahwa sistem bagi hasil yang diterapkan antara pemilik lahan dan petani penggarap di Kabupaten Gorontalo dapat memberikan dampak positif bagi peningkatan penghasilan (perekonomian) para pemilik lahan sekaligus meningkatkan pendapatan para petani penggarap.

Abdul Kadir menerangkan bahwa dalam situasi dan kondisi masyarakat Gorontalo, khususnya masyarakat petani di Kabupaten Gorontalo sekarang ini, di mana pemilik lahan yang penghidupannya berada di atas garis kemiskinan (ekonomi menengah atau atas) senantiasa memperlihatkan sifat kemanusiawian yang berasaskan Islam. Hal ini terbukti karena walaupun penghasilan lahannya tetap mereka ambil setelah biaya yang dikeluarkan dalam pengurusan tanahnya itu, akan tetapi seringkali pula mereka memberikan berupa sedekah kepada petani yang menggarap kebunnya, sehingga penghasilan petani penggarapnya bertambah dan memotivasi untuk bekerja lebih jujur dan adil. $^{46}$

Dengan demikian, jika diperhatikan beberapa keterangan singkat yang dikemukakan oleh petani penggarap di atas, maka dapat disimpulkan bahwa dampak bagi hasil terhadap aspek perekonomian petani penggarap adalah berdampak positif, yakni menambah penghasilan pendapatan perkapita sekaligus dapat meningkatkan taraf perekonomian para petani penggarap, sehingga kebutuhan hidup keseharian petani penggarap dapat terpenuhi.

\footnotetext{
${ }^{45}$ Ali Bilondatu, Petani Penggarap, Wawancara di Desa Lupoyo Kabupaten Gorontalo, tanggal 14 Nopember 2016.

${ }^{46}$ Abdul Kadir, Petani Penggarap, Wawancara di Desa Dumati Kabupaten Gorontalo, tanggal 14 Nopember 2016.
} 


\section{E. Kesimpulan}

Berdasarkan pemaparan di atas, maka dapat ditarik kesimpulan sebagai berikut:

1. Bentuk pelaksanaan sistem bagi hasil bagi petani penggarap di Kabupaten Gorontalo memberikan adalah dengan melakukan akad perjanjian dan prosentase pembagian hasil yang telah disepakati bersama. Proses kerjasama dalam pertanian ini salah satu diantaranya adalah menyewakan lahan kepada orang (petani penggarap) dengan sistem bagi hasil. Hal ini adalah lebih baik dari pada lahan tidak terolah atau tidak menghasilkan sama sekali asalkan sistem bagi hasil itu diterapkan sesuai kesepakatan bersama.

2. Faktor yang menyebabkan terjadinya sistem bagi hasil dalam produksi pertanian adalah karena adanya sistem penguasaan atas tanah di satu pihak dan ketiadaan lahan bagi pihak lain.

3. Dampak yang ditimbulkan dengan adanya sistem bagi hasil petani penggarap di Kabupaten Gorontalo adalah memberikan dampak yang positif, di mana mendapatkan penghasilan yang memadai untuk menafkahi keluarganya, sehingga tarap perekonomian masyarakat petani penggarap dapat terangkat pula adanya.

\section{DAFTAR PUSTAKA}

Al-Qur'ān al-Karìm.

Ali, Mohammad Daud. Hukum Islam, Pengantar Ilmu Hukum dan Tata Hukum di Indonesia, Ed. 5. Cet. V; Jakarta: Raja Grafindo Persada, 1996.

Bakry, Hasbullah. Pedoman Islam Indonesia. Cet. V; Jakarta: UI Press, 1990.

Al-Bukhārì, Abì 'Abdillah Muḥammad bin Ismā'il bin Ibrāhim bin alMugirah bin Barẓabah. Șậịh al-Bukhārī, Juz 8. Bairūt: Dār alKutub al-'Ilmiyyah, $1992 \mathrm{M} / 1412 \mathrm{H}$.

Hasan, M. Ali. Berbagai Macam Transaksi dalam Islam (Fiqh Muamalat), Ed. 1. Cet. I; Jakarta: PT RajaGrafindo Persada, 2003. 
Ibn Qasim, Al-Allamah Syekh Muhammad. Fath al-Qarib, terj. H. Abubakar Muhammad, Fiqih Islam (Terjemah Fath al Qarib). Surabaya: Karya Abitama, 1995.

Al-Jazirī, Abd al-Raḥmān. Al-Fiqh 'ala Maz̄āhib al-'Arba'ah. Bairūt: Dār al-Qalam, t.th.

Kementerian Agama RI.. Ummul Mukminin: Al-Qur'an dan Terjemah Untuk Wanita. Jakarta Selatan: Penerbit Wali, 2010.

Kementerian Pertanian. Statistik Lahan Pertanian Tahun 2009-2013, Statistics of Agricultural Land 2009-2013 (Jakarta: Pusat Data dan Informasi Pertanian Sekretariat Jenderal Kementerian Pertanian, 2014.

Al-Naisaburīi, Imām Muslim ibn al-Hajāj al-Qusyairī. Șahịh Muslim, Juz 8. Bairūt: Dār al-Kutub al-'Ilmiyah, t.th.

Pasaribu Chairuman, dan Suhrawardi K. Lubis. Hukum Perjanjian Dalam Islam. Cet. II; Jakarta: Sinar Grafika, 1996.

Al-Qayubi Syaikh Syihab al-Din, dan Syaikh Umairah, Qalyubi wa Umairah. Indonesia: Dar al-Ihya al-Kutub al-Arabiyah, t.th.

Rahman, Afzalur. Economic Doctrines of Islam, terj. Soeroyo dan Nastangin, Doktrin Ekonomi Islam, Jil. II. Cet. III; Jakarta: Dana Bhakti Wakaf, 1995.

Sabiq, Sayyid. Fiqh Sunnah. Bairūt: Dār al-Fikr, 1977.

Sabiq, Sayyid. Fiqh Sunnah: Edisi Terjemahan, Jil. IX (Semarang: Toha Putra, 1998.

Ash-Shiddieqi, Hasbi. Pengantar Fiqh Muamalah. Jakarta: Bulan Bintang, 1984.

Siddiqi, M. Nejatullah. Partnership and Profit Sharing in Islamic Law, terj. Fakhriyah Mumtihani, Kemitraan Usaha dan Bagi Hasil dalam Hukum Islam, Ed. I. Cet. I; Jakarta: Dana Bhakti Yasa, 1996.

Suhendi, Hendi. Fiqh Muamalah, Ed. 1. Cet. IX; Jakarta: Rajawali Pers, 2014.

Taqiyyuddin, Abi Bakr ibn Muhammad. Kifayat al-Akhyar. Bandung: Alma'arif, t.th..

Usmān, Muhammad. Al-Rizq al-Halal wa al-Hakikah al-Tawakkal alAllāh (Kairo: Matahabbah al-Qur'ān, 1972. 